\title{
Диференційований підхід до оцінювання рівня та стану багаторівневих показників на прикладі економічної безпеки підприсмства
}

\begin{abstract}
Здійснено критичний огляд існуючих методик та підходів до оиінювання рівня та стану економічної безпеки підприємства як одного із відомих багаторівневих показників. Узагальнено напрямки існуючих досліджень у чотири групи. Уперше запропоновано диференційований підхід до оцінювання рівня багаторівневого показника відокремлено від його стану. Запропоновано під рівнем багаторівневого показника розуміти порівняльну величину, яка характеризуе ступінь досягнення ним певного значення у конкретний момент часу. У статті надане визначення стану багаторівневого показника, у т.ч. економічної безпеки підприємства, як комплексного поняття, щзо визначається сукупністю обставин $i$ умов, в яких перебуває підприємство, зважаючи на наявні на ньому ресурси, резерви й прочеси та відображає можливості відновлення необхідних (базових) властивостей багаторівневого показника 3 урахуванням необхідного на це часу $і$ тенденцій, що склалися на цьому підприємстві без вжиття спеціальних заходів. Обтрунтовано методичні відмінності між оцінкою рівня та оцінкою стану багаторівневого показника. Наведено приклади окремих випадків, в яких результати застосування диференційованого підходу можуть мати суперечливий характер. Уперше запропоновано ввести у науковий термінологічний обіг показник «індикатор необхідності управлінських впливів» та надано формулу його визначення. Сформовано блок-схему застосування диференційованого підходу до оцінювання багаторівневих показників. Виявлено, щео в окремих випадках при оціниі стану багаторівневого показника застосування в якості періоду обмеження довжини циклу Кітчина є не доцільним. Показано, щчо події, які не вкладаються у загальну ситуацію та усталений тренд по підприємству доиільно розглядати окремо та назвати переломні події. Обтрунтовано, щчо при наявності переломних подій доцільно скористатися методичним підходом, який передбачає приведення різних часових показників - обмежувачів (наприклад таких, як довжина циклу Кітчина та граничний термін несплати за поточними зобов'язаннями при впровадженні справи про банкрутство) до однакової шкали.
\end{abstract}

Ключові слова: бажаний тренд; переломна подія; показники часу; рівень багаторівневого показника; стан багаторівневого показника.

Актуальність теми. Сучасні економічні дослідження відрізняються широкою номенклатурою методик і підходів до оцінювання одних i тих самих економічних показників, у тому числі i багаторівневих. Зокрема, один із таких ключових багаторівневих показників, як фінансово-економічний стан підприємства характеризується різноманітністю не тільки авторських підходів, але й інтерпретацією результатів оцінювання: одні науковці диференціюють його рівні (здебільшого за шкалою Харрінгтона дуже низький, низький, середній, високий та дуже високий), а інші - стани (наприклад, стійкий, нестійкий, кризовий). Аналогічне зауваження стосується й економічної безпеки підприємства, відносно якої слід визнати не тільки широту поглядів на ії сутність, але й також не меншу розгалуженість підходів та методик оцінювання. При цьому за наявної різноманітності методичних підходів до оцінки слід указати на відсутність єдиної думки серед науковців щодо предмету оцінювання - це стан економічної безпеки чи їі рівень. Вирішення цього завдання є важливим не тільки з огляду на необхідність уточнення методології оцінювання економічної безпеки, але й для визначення напрямів подальших управлінських впливів, спрямованих на підвищення рівня економічної безпеки та/або на поліпшення їі стану.

Аналіз останніх досліджень та публікації, на які спирається автор. Науковцями Г.В.Козаченко та Ю.С. Погореловим надане визначення такого поняття як «підхід до оцінювання економічної безпеки підприємства», який вони трактують як «сукупність однотипних прийомів та способів вимірювання рівня економічної безпеки» [1, с.239]. Указання на рівень економічної безпеки підприємства як об'єкт оцінювання економічної безпеки зроблено також у роботі Г.М. Черняк [2, с.162].

Д.І. Коваленко та В.О. Нехороших, аналізуючи методи оцінки рівня фінансово-економічної безпеки, при цьому називають причини загострення стану фінансово-економічної безпеки (ухвалення неадекватних управлінських рішень відносно залучення та раціонального використання фінансових ресурсів) [3, с.37].

Л.В. Гнилицька, розглядаючи критерій економічної безпеки як вимірник стану суб'єкта господарювання з точки зору відповідності фактично досягнутих показників його діяльності заздалегідь встановленим індикаторам, які відображають сутність економічної безпеки, визначає критеріальну оцінку стану економічної безпеки [4, с.47]. На думку науковця, вона включає в себе оцінку ресурсного потенціалу та узгодженості інтересів усіх учасників у середині підприємства, при яких загрози внутрішнього та зовнішнього характеру зводитимуться до мінімуму. Для достовірної оцінки стану економічної безпеки науковець пропонує розробити модель, яка б забезпечила можливість максимально точного розрахунку значення критерію економічної безпеки підприємства, підгрунтям якої названо 
систему показників (індикаторів), які відображають сутність та економічний характер процесів, якими характеризується суб’єкт господарювання» [4, с.47].

Надалі Л.В. Гнилицька надає групування підходів та методів оцінки «стану та рівня» економічної безпеки підприємств: індикаторний, економіко-математичний, ресурсно-функціональний, прибутковоінвестиційний підходи та програмно-цільовий, аналізу і обробки сценарії, ігрові методи, а також модель оцінки рівня безпеки на основі показника економічної дієвості [4, с.48]. Проте при розкритті сутності кожного 3 них, зазначається, що вони застосовуються для оцінки рівня економічної безпеки. Відтак не дивлячись на заявлену назву статті, Л.В. Гнилицькою не розмежовується оцінка стану від оцінки рівня економічної безпеки підприємства.

Аналогічне зауваження доцільно висловити до наукової праці В.А. Воропай, в якій вищезгадані (а також додатково розглянуті: підхід до оцінки стану фінансової складової діяльності підприємства, підхід, заснований на прогнозуванні банкрутства) названі «методичними підходами щодо оцінки системи економічної безпеки підприємства» [5, с.191]. Ті самі підходи (зокрема, індикаторний, ресурснофункціональний, програмно-цільовий) вченими М.П. Денисенко й П.Т. Колісніченко [6, с.33], а також О.М. Сумець й А.В. Короп [7, с.126] названо підходами для визначення стану економічної безпеки, а науковцем Ю.М.Якименко - підходами до визначення основних показників економічної безпеки $[8$, c.135].

Д.В. Бутнік надає визначення критерію економічної безпеки як оцінки їі стану з точки зору найважливіших процесів, які відображають сутність економічної безпеки, але при цьому ж зауважує, що для оцінки рівня економічної безпеки насамперед важливі не стільки показники, скільки порівняння їх 3 нормативними (пороговими) значеннями; на його думку ступінь економічної безпеки визначається мірою наближення показників до порогових значень [9].

Ототожнення понять «оцінка стану» та «оцінка рівня» економічної безпеки спостерігається також і в ряді інших праць, при чому не тільки вітчизняних учених, але й науковців пострадянського простору. Зокрема, науковці Є.А. Козлобаєва та С.І. Яблоновська, досліджуючи стан економічної безпеки сільськогосподарського підприємства та використовуючи для прикладу дані конкретного товариства, наводять таблицю із назвою «Стан економічної безпеки ТОВ «ЕкоНиваАгро», але у стовбцях самої таблиці ними зазначено різні рівні безпеки за окремими складниками безпеки. Водночас науковцями диференційовані такі рівні: абсолютний, нормальний, нестабільний, критичний та кризовий [10, с.178]. При цьому умовам абсолютного рівня економічної безпеки відповідає, на думку Є.А. Козлобаєвої та C.I. Яблоновської, відсутність будь-яких економічних збитків у результаті досягнення найвищого рівня реалізації економічних можливостей та максимально можливого захисту економічних інтересів підприємства [10, с.176]. Вважаємо такий висновок вкрай важливим за одним зауваженням: абсолютного рівня економічної безпеки практично неможливо досягти, особливо якщо це стосується господарювання у ринковому середовищі, а тому все зазначене науковцями має місце, але при високому (дуже високому), а не абсолютному рівні економічної безпеки.

Отже, вважаємо доцільним указати на упущення науковців, яке полягає в ототожненні понять «оцінка рівня» та «оцінка стану» економічної безпеки та відповідно не розмежуванні відповідних підходів і методик оцінювання.

Науковцем В.П. Приходько акцентовано увагу на чотирьохетапній методиці оцінки стану економічної безпеки, яка базується на експертних судженнях (перший етап передбачає аналіз мотивів економічної поведінки підприємств, процесів прийняття стратегічних та тактичних рішень, взаємоузгодження інтересів 3 іншими суб'єктами економічної діяльності; другий - узагальнення дослідженого комплексу ситуацій на основі експертних карт; третій - класифікація досліджених ситуації за заданими критеріями; четвертий - побудова логіко-структурних моделей) [11, с. 36].

На оцінюванні стану економічної безпеки підприємства зосереджено увагу також науковця Ю.М. Якименко [8, с.136]. Окрім цього, у його праці містяться ряд важливих тверджень згідно $з$ якими не доцільно ототожнювати систему економічної безпеки організації з їі діяльністю й ефективністю. Для цього, на його думку, іiі складниками повинні бути автономні блоки (останні відповідають зокрема, за вплив зовнішнього середовища (впливу загроз), ресурсне забезпечення, якість реалізації функцій управління (планування, облік, аналіз тощо) та вивчають проблеми i ïx вирішення по окремим підсистемам, але з урахуванням цілей і завдань системи в цілому). У зв'язку із цим загальну оцінку стану економічної безпеки організації Ю.М. Якименко характеризує як таку, що складається з оцінок систем, які розташовані на попередньому рівні ієрархії управлінсько-організаційної структури, і в розрізі тих завдань, які поставлені в даний час» $[8$, с.136].

Отже, перелік існуючих поглядів на оцінювання стану економічної безпеки можна було б продовжувати, оскільки він є надзвичайно широким, а пропоновані науковцями методики та підходи вирішують поставлені їх авторами конкретні завдання. Проте у межах нашого дослідження, 3 урахуванням обмеженості обсягу праці, зупинимося на вже розглянутих і підкреслимо наявність окремого напрямку досліджень оцінювання саме «стану» економічної безпеки підприємств. 
Далі розглянемо окремі наукові праці, в яких актуалізована оцінка рівня економічної безпеки. Зокрема, цікавий підхід до оцінювання рівня економічної безпеки підприємства запропонувати вчені С.Б. Довбня та Н.Ю. Гічова, які назвали його «Тримірна діагностика рівня економічної безпеки підприємства» [12, с.37]. Відповідно до нього оцінюється кількісне значення рівнів поточної, тактичної та стратегічної економічної безпеки на підставі середньозваженої міри досягнення фактичних значень відповідних оціночних показників своїм установленим цільовим (рекомендованим значенням) за формулою [12, с.39]:

$$
\Pi(\text { Тк; С })=\frac{\sum_{\mathrm{j}=1}^{\mathrm{m}} 3 j \times\left(\frac{K j}{N j}\right)^{l}}{\sum_{\mathrm{j}=1}^{\mathrm{m}} 3 j}
$$

де П - рівень поточної економічної безпеки підприємства;

Тк - рівень тактичної економічної безпеки підприємства;

$\mathrm{C}$ - рівень стратегічної економічної безпеки підприємства;

$3 j$ - коефіцієнт значущості $j$-того показника, що визначається експертним шляхом;

$K j$ - фактичне значення $j$-того показника;

$N j$ - рекомендоване (нормативне) значення $j$-того показника;

m - кількість використовуваних для оцінки показників відповідної складової;

$l$ - ступінь, який приймає значення $l$, якщо зростання значення показника свідчить про підвищення рівня економічної безпеки, і -1, якщо зростання значення показника негативно вливає на безпеку підприємства.

Загальний рівень економічної безпеки (ЕБ) визначається середньою величиною показників поточної, тактичної та стратегічної безпеки, зважених на відповідні коефіцієнти значущості [12, с.40]:

$$
\mathrm{EБ}=\frac{(l) \times \Pi+(\Pi) \times \mathrm{T}+(\Pi \times \mathrm{T} \kappa) \times C}{(1)+(\Pi)+(\Pi \times \mathrm{T} \kappa)},
$$

де $(l),(\Pi),(П \times$ Тк) - коефіцієнти значущості поточної, тактичної та стратегічної

безпеки відповідно.

С.Б. Довбня та Н.Ю. Гічова диференціювали окремі рівні економічної безпеки підприємства залежно від значень показника ЕБ та протиставили кожному рівню відповідні стани безпосередньо підприємства $[12$, c.41]:

$0,00<$ ЕБ $<0,25$ - надто низький рівень економічної безпеки;

$0,25<$ ЕБ $<0,50$ - низький рівень економічної безпеки;

$0,50<$ ЕБ $<0,75$ - нестійкий рівень економічної безпеки;

$0,75<$ ЕБ $<0,95$ - задовільний рівень економічної безпеки;

$0,95<$ ЕБ - високий рівень економічної безпеки.

Разом із цим, тільки високому рівню економічної безпеки науковці віднесли відповідний стан економічної безпеки, який назвали «абсолютний». Проте ми не можемо погодитися 3 диференціацією «абсолютного стану економічної безпеки», оскільки в практичній діяльності суб'єктів господарювання він майже не зустрічається, про що вже зазначили вище.

Науковцями Н.С. Артамоновою та А.В. Атрашковою окремо розглядається оцінювання рівня економічної безпеки, але при цьому надається характеристика відповідності його значень умовам стану безпеки з урахуванням експертних оцінок. На увагу заслуговує твердження науковців про те, що оцінка рівня економічної безпеки підприємства пов'язана 3 фактом визначення прибутковості його виробничогосподарської діяльності [13, с.21], а недостатність рівня економічної безпеки призводить до підвищення імовірності банкрутства підприємства та його можливої ліквідації [13, с.23]. Для визначення рівня економічної безпеки Н.С. Артамонова та А.В. Атрашкова запропонували коефіцієнт стійкості економічного стану підприємства (Ксес) [13, с.22]:

$$
\text { Ксес }=\frac{\text { Реінвестований прибуток }}{\text { Власний капітал на кінець періоду }}=\frac{\Delta \mathrm{PK}+\Delta \mathrm{HPП}}{\text { Власний капітал на кінець періоду }}
$$

де $\Delta \mathrm{PK}$ - різниця між сумою чистого прибутку, яка спрямована на формування резервного капіталу на кінець періоду та відповідною сумою на початок цього періоду, грн.;

$\Delta$ НРП - різниця між сумою нерозподіленого прибутку, що формується 3 чистого прибутку підприємства на кінець періоду та відповідною сумою на початок цього періоду, грн.

Класифікація рівнів економічної безпеки у лінгвістичних термах залежно від значень показника Ксес має такий вигляд [13, с.23]:

Ксес $\leq 0,05$ - підтримуючий рівень економічної безпеки;

$0,06 \leq$ Ксес $\leq 0,1$ - мінімальний рівень економічної безпеки;

$0,11 \leq$ Ксес $\leq 0,29$ - низький рівень економічної безпеки;

$0,3 \leq$ Ксес $\leq 0,49$ - середній рівень економічної безпеки;

$0,5 \leq$ Ксес $\leq 0,7$ - високий рівень економічної безпеки;

Ксес $>0,7$ - дуже високий рівень економічної безпеки. 
Підкреслимо, що автори праці [13, с.23] залежно від вищенаведених рівнів диференціювали окремі стани економічний безпеки. Так, підтримуючому рівню відповідає нестійкість економічної безпеки, а при мінімальному - підприємство, на думку Н.С. Артамонової та А.В. Атрашкової, знаходиться, в економічній безпеці і в змозі ії підтримувати найближчим часом; низький і середній рівні пов'язані 3 обсягами інвестиційної підтримки умов економічної безпеки; високий рівень характеризує стан економічної безпеки, який дозволяє утримати стратегічні позиції та значні конкурентні переваги і тільки дуже високому рівню відповідає такий стан економічної безпеки підприємства, який дозволяє мати суттєві конкурентні переваги стратегічного характеру та стати лідером ринку у галузі з можливостями забезпечення успішної діяльності на міжнародних ринках [13, с. 23].

Однак слід відмітити, що не дивлячись на спробу протиставити рівень та стан економічної безпеки та певним чином співвіднести їх між собою, в роботі Н.С. Артамонової та А.В. Атрашкової [13] визначення стану економічної безпеки є не кількісним, а якісним. Крім цього, відсутня методика окремого визначення стану економічної безпеки підприємства.

Отже, проведений аналіз фахової літератури з питань безпекології, дозволяє зробити висновок про наявність чотирьох напрямів досліджень:

- за першим із них, найбільш розповсюдженим, «оцінка рівня» та «оцінка стану» економічної безпеки представляється науковцями одним і тим самим, через що в одному дослідженні обидва термінами вживаються упереміш та ототожнюються;

- за другим напрямом увага науковців більше зосереджена на оцінці стану економічної безпеки підприємства, а про рівень мова не йде взагалі;

- за третім напрямом вчені оцінюють рівень економічної безпеки підприємства (в окремих випадках протиставляючи йому стан самого підприємства);

- за четвертим напрямом, найменш розробленим, науковцями розмежовуються оцінка рівня економічної безпеки та визначення його стану, але останній виступає якісною характеристикою рівня.

Крім того, вважаємо, що науковці, надаючи власні, авторські методики оцінювання чи то рівня, чи стану багаторівневого показника протиставляють їх іншим методикам, але насправді вони вирішують різні завдання.

У зв'язку із відсутністю єдиного напрямку досліджень, вважаємо доцільним уточнити та вдосконалити методичний підхід до оцінювання рівня та стану економічної безпеки підприємства.

Метою статті є розробка диференційованого підходу до відокремленого оцінювання рівня та стану багаторівневих показників на прикладі економічної безпеки підприємства.

Викладення основного матеріалу. Погоджуючись 3 існуючою серед науковців думкою, що між діяльністю підприємства та життедіяльністю людини можна проводити аналогії, розглянемо такий умовний приклад. Дві людини захворіли однією й тою самою хворобою, наприклад, застудилися. У них піднялася температура до 38 градусів. При цьому переносять таку температуру та хворобу вони порізному: одна легше, навіть не втратила працездатність, а інша людина - зовсім тяжко, злягла на постільний режим. Більше того, при застуді взагалі не в кожної людини піднімається температура. При одному рівні температури стан у людей різний. Одужання також відбувається по-різному: по-перше, одна людина одужує швидше, а інша набагато повільніше; по-друге, різною є потреба в сторонній допомозі, зокрема в ліках (одна людина лікується «легшими» засобами, наприклад, трав'яними настоями, а іншій людині потрібен не один курс антибіотиків) тощо. Різним є не тільки протікання хвороби, але й результат, яким, своєю чергою, може бути повне одужання, розвиток хронічного перебігу захворювання або смерть. Протікання хвороби та кінцевий результат залежатимуть від ряду чинників, серед яких термін діагностики та постановки правильного діагнозу, методика лікування. Проте за однакових умов щодо діагностування та схем лікування, слід указати на такий чинник як внутрішні сили й резерви організму людини.

Отже, розглянутий приклад яскраво ілюструє, що поняття «рівень» і «стан»є різними та їх не доцільно ототожнювати. Для з'ясування змісту цих понять звернемося до тлумачного словника української мови:

- стан - це обставини, умови, в яких хто-, що-небудь перебуває, існує; ситуація, зумовлена певними обставинами, умовами (словник української мови: в 11 томах, том 9, 1978 р., с. 643);

- рівень - це ступінь якості, величина і т. ін., досягнуті у чому-небудь (словник української мови: в 11 томах, том 8, 1977 р., с. 547).

Для уточнення понятійного апарату у межах даного дослідження пропонуємо під рівнем багаторівневого показника розуміти порівняльну величину, яка характеризує ступінь досягнення ним певного значення у конкретний момент часу. Під рівнем економічної безпеки підприємства пропонуємо вважати порівняльну величину, яка характеризує ступінь досягнення ним економічної безпеки у конкретний момент часу. Рівень багаторівневого показника (у т.ч. економічної безпеки) може визначатися як кількісно, так і якісно, мати цифрове вираження та відповідний йому лінгвістичний терм. Вважаємо, що всі вище розглянуті підходи та методики оцінювання економічної безпеки, які достатньо 
широко висвітлені у фаховій літературі, є не чим іншим, як визначенням іiі рівня. Розглянуті підходи, переважно, базуються на оцінці значень показників, розрахованих на конкретний момент часу. Тому оцінка рівня багаторівневого показника (у т.ч. економічної безпеки) є певним моментним зрізом. Оцінка рівня, переважно, є ретроспективною і характеризує констатацію факту. В умовному прикладі 3 хворобою людини, рівнем була температура тіла.

Стан багаторівневого показника, у т.ч. економічної безпеки підприємства, на нашу думку, $є$ комплексним поняттям, що визначається сукупністю обставин і умов, в яких перебуває підприємство, зважаючи на наявні на ньому ресурси, резерви й процеси та відображає можливості відновлення необхідних (базових) властивостей багаторівневого показника з урахуванням необхідного на це часу і тенденцій, що склалися на цьому підприємстві. Безпосередньо методику оцінювання багаторівневих показників, у т.ч. економічної безпеки підприємства 3 використанням показників часу ми надали в ряді наших робіт, зокрема в [14, с. 36]. Тому, на наш погляд, оцінка стану економічної безпеки підприємства базується на визначенні часу, необхідного для досягнення показників, які характеризують їі рівень, своїх заданих (нормативних, еталонних, рекомендованих, планових) значень з урахуванням існуючих на даний момент резервів, ресурсів і процесів та зважаючи на наявні тенденції. Іншими словами, стан багаторівневого показника характеризується його існуючим рівнем, наявними ресурсами (традиційними та нетрадиційними), звичайно задіяними бізнес-процесами, прийнятою практикою ведення бізнесу (господарювання загалом та фінансовою політикою зокрема), що у своїй сукупності показує, чи зможе взагалі і через який час підприємство змінити досягнутий рівень «власними силами». Якщо розрахована величина часу $є$ неприйнятною та характеризує, наприклад, незадовільний стан економічної безпеки підприємства, то це вказує на необхідність здійснення відповідних управлінських впливів.

Таким чином, відмінність між оцінкою рівня та оцінкою стану багаторівневого показника (у т.ч. економічної безпеки підприємства) полягає в тому, що в першому випадку визначається ретроспективний зріз за певними монопоказниками, які характеризують багаторівневий показник як результуючий, а в другому випадку підприємству доцільно задати максимальний проміжок часу (яким за нашою методикою $є$ період циклу $[14$, с. 43]) і спрогнозувати зміни (кількісні та якісні, у часі та просторі) цих монопоказників за встановлений період без будь-яких управлінських впливів 3 його боку. Відтак рівень $є$ величиною, яка вже отримана, при чому в цілях оцінки підприємство не цікавить, яким чином вона одержана; рівень - це даність і зафіксований факт. На відміну від нього, при оцінці стану здійснюється прогноз стосовно часу, через який підприємство зможе вийти на належний (заданий, бажаний, плановий, нормативний, еталонний тощо) рівень за допомогою наявних, як вже зазначалося, ресурсів та джерел їх фінансування, а також використовуваних у звичайній діяльності підприємства бізнес-процесів, що будуть задіяні при цьому.

Рівні економічної безпеки, на наш погляд, можуть бути такими: високий, середній, низький та мінімальний. Стани економічної безпеки пропонуємо розглядати у межах таких інтуїтивно зрозумілих терм: відмінний стан, добрий стан, задовільний стан та незадовільний стан.

Отже, відокремлена оцінка рівня багаторівневого показника (у т.ч. економічної безпеки) від оцінки його (iii) стану становить суть диференційованого підходу (у т.ч. до оцінювання економічної безпеки), який схематично можна подати так, як це зображено на рис. 1

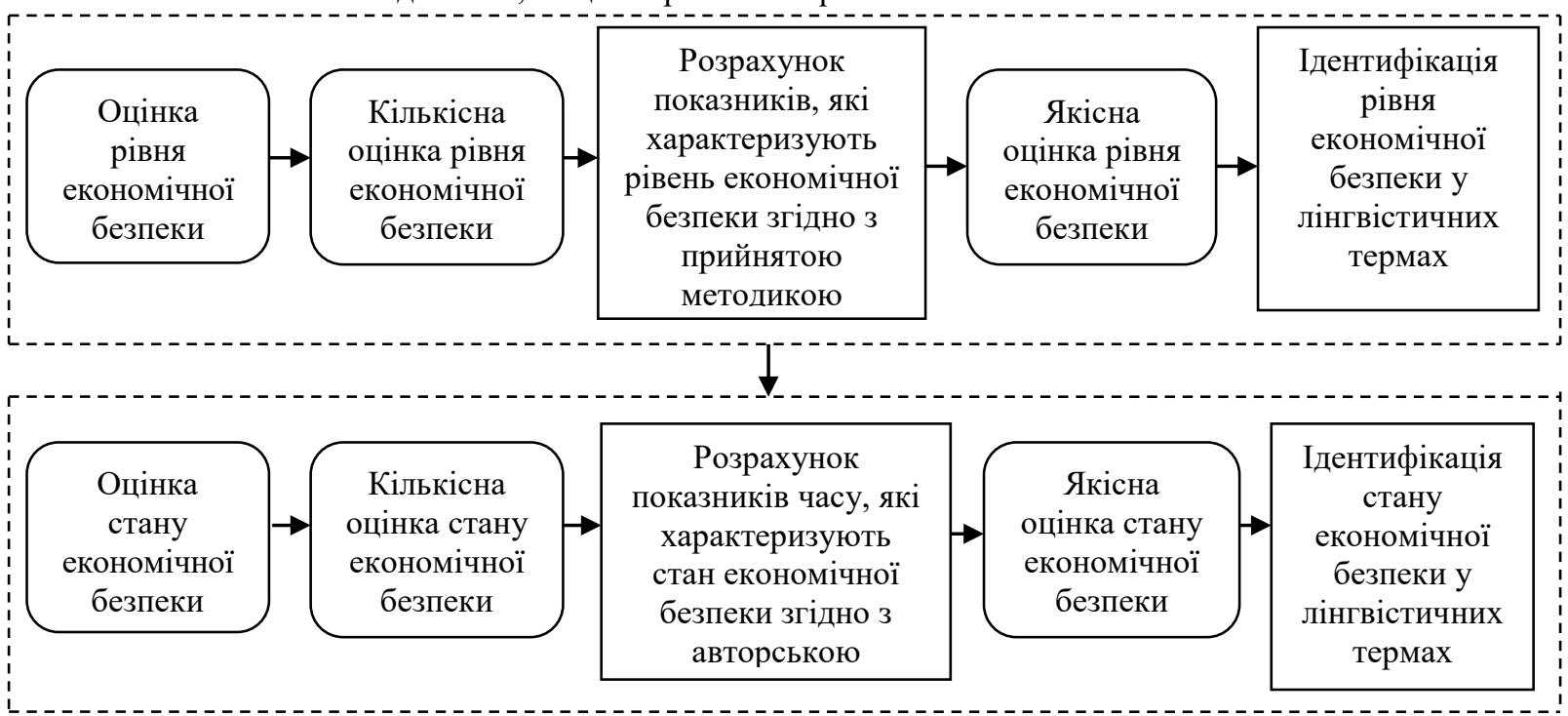

Рис. 1. Схематичне представлення диферениійованого підходу до оцінювання рівня та стану економічної безпеки підприємства 
В окремих випадках результати застосування диференційованого підходу можуть виявитися в наступних суперечливих ситуаціях:

- на підприємстві достатньо як коштів, так і інших ресурсів та джерел їх формування, а також прибутку для досягнення рівності фактичних величин відповідних показників економічної безпеки своїм заданим значенням, але при цьому часу на це вже не вистачає. Така ситуація, на нашу думку, може бути викликана змінами у зовнішньому середовищі підприємства, форс-мажорними обставинами, а також, переважно, неякісною фінансовою політикою, у тому числі при розрахунках 3 контрагентами, та пов'язана із обмеженнями 3 боку державних нормативно-правових актів (особливо законодавством 3 питань банкрутства);

- відповідні показники економічної безпеки не відповідають своїм заданим (нормативним, еталонним, бажаним, плановим, рекомендованим, необхідних) значенням на момент оцінки, але у межах заданого проміжку часу (довжина циклу Кітчина) ця ситуація виправляється. Такі обставини $є$ менш загрозливими для підприємства, оскільки у разі реалізації управлінських рішень з'являється можливість навіть скоротити час досягнення монопоказниками необхідних значень.

Отже, значення рівня та стану дуже тісно корелюють між собою (наприклад, високий рівень відмінний стан). Невідповідність якісних терм рівня та стану провокується, здебільшого, зовнішніми чинниками, у тому числі зміною законодавства. Наприклад, підприємства гірничо-збагачувального комплексу перебували у кризовому стані (низький рівень безпеки), але із віднесенням їх до стратегічно важливих для економіки та безпеки держави, у т.ч. введенні мораторію на задоволення вимог кредиторів тощо, їх стан різко і стрімко покращувався. Можна навести і протилежний приклад, коли виробників скляних пляшок для молочних продуктів витіснили інші підприємства, які виготовляли упаковки тетрапак, поліетиленові пакети та пластикові пляшки. У такому разі рівень фінансово-економічного стану (а також економічної безпеки) перших виробників був до певного моменту високим, але їх стан швидко погіршився через появу конкурентів із більш сильними позиціями на ринку.

Відтак час (Тк), що є однорідним комплексним показником, який характеризує стан економічної безпеки та показує, як і куди рухається підприємство і залежить від рівня, ресурсів й процесів, що наявні в розпорядженні підприємства у заданий проміжок часу без додаткових втрачань з боку керівництва:

Тк = f (Рівень; Ресурси; Процеси).

Кожне підприємство, з урахуванням його специфіки та особливостей, які склалися за час практики господарювання рухається за певним трендом. Якщо зміни і все те, що відбувається протягом такого руху є бажаними та влаштовують керівництво і власників підприємства, то такий тренд пропонуємо назвати бажаним (зразковим, еталонним, нормативним, усталеним, традиційним). Якщо такий бажаний тренд змінюється та стає гіршим, то це сигналізує про необхідність втручання та вжиття управлінських заходів. Крім того, слід указати, що при одних і тих самих умовах, одне підприємство здатне виправити наявний негативний тренд, а інші - ні.

Таким чином, пропонуємо ввести у науковий термінологічний обіг показник «індикатор необхідності управлінських впливів» (ІНУВ), який визначається формулою:

IНУВ = Фактичний тренд - Бажаний тренд.

Блок-схема застосування диференційованого підходу до оцінювання багаторівневих показників (у т.ч. економічної безпеки) представляється нами наступним чином (рис. 2).

Стосовно оцінювання стану багаторівневого показника слід відмітити, що в окремих випадках застосування в якості періоду обмеження довжини циклу Кітчина є не доцільним. Зокрема, це стосується обставин і подій, в яких є критичні (переломні) обмеження за часом, наприклад при розрахунках із кредиторами, під час яких порушення встановлених термінів (які набагато коротші за вказаний цикл) загрожує підприємству впровадженням справи про банкрутство. Подібні події, які не вкладаються у загальну ситуацію та усталений тренд по підприємству пропонуємо називати переломні події. При наявності переломних подій доцільно скористатися іншим методичним підходом, який передбачає приведення різних часових показників - обмежувачів (наприклад таких, як довжина циклу Кітчина та граничний термін несплати за поточними зобов'язаннями при впровадженні справи про банкрутство) до однакової шкали. Відповідно знаменник формул в роботі $[14$, с. 43] замість періодів циклу матиме інший вигляд. 3 цією метою необхідно зберегти існуючі кількісні пропорції діапазонів між межами шкали по кожній виокремленій в ній групі відповідних лінгвістичних терм стану економічної безпеки (або іншого багаторівневого показника) та розрахувати нові скореговані межі. Слід урахувати, що нижня межа при цьому дорівнюватиме нулю, оскільки показники часу повинні прагнути до зменшення.

Висновки та перспективи подальших досліджень. Таким чином, на відмінну від існуючих методик оцінювання рівня та стану багаторівневих показників, нами обгрунтовано, що це дві різні оцінки, під час яких вирішуються різні завдання. Оцінка рівня багаторівневого показника характеризує певний ретроспективний зріз. Оцінка стану багаторівневого показника грунтується на визначенні досягнутого рівня, наявних ресурсів, резервів і процесів, а також ураховує загальні тенденції, що склалися на 
підприємстві та передбачає прогноз часу, протягом якого рівень цього показника зміниться без спеціального втручання та управлінських впливів.

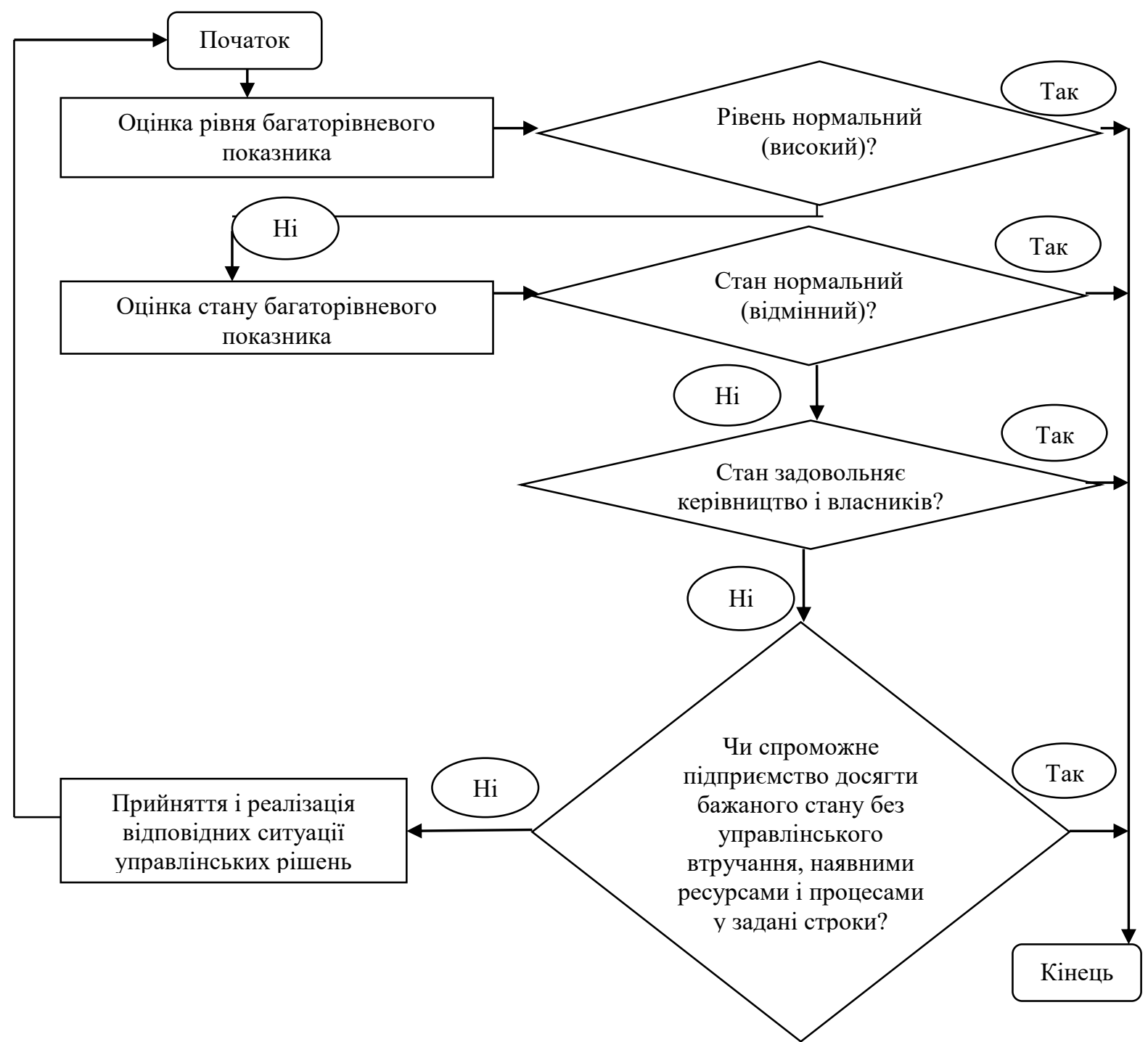

Рис. 2. Блок-схема застосування диферениійованого підходу до оичінювання рівня та стану багаторівневого показника

Подальшим напрямком наших досліджень $\epsilon$ розробка конкретних управлінських заходів, спрямованих як на покращення стану економічної безпеки, так і на підвищення ії рівня.

Список використаної літератури:

1. Козаченко Г.В. Оцінювання економічної безпеки підприємства: аналіз основних підходів. Менеджмент безпеки держави, регіону, підприємства: проблеми і виклики сьогодення : кол. монографія / Г.В. Козаченко, Ю.С. Погорелов ; за заг. ред. З.Б. Живко, І.Г. Бабеиь. - Львів : Ліга-Прес, 2015. - С. 238-251.

2. Черняк Г.М. Оцінювання рівня економічної безпеки енергетичних підприємств в умовах євроінтеграції / Г.М. Черняк // Економічний вісник Національного технічного університету України «Київський політехнічний інститут». - 2015. - № 12. - С. 159-166.

3. Коваленко Д.І. Оцінювання рівня фінансово-економічної безпеки підприємства в умовах нестабільності: теоретико-методичний аспект / Д.І. Коваленко, В.О. Нехороших // Інтернаука : міжнародний науковий журнал. Серія : Економічні науки. - 2017. - № 6 (6). - С. 33-38.

4. Гнилицька Л.В. Аналіз методологічних підходів до оцінки стану та рівня економічної безпеки суб'єктів господарювання / Л.В. Гнилицька // Науковий вісник Львівського державного університету внутрішніх справ. Серія : Економічні науки. - 2011. - № 2. - С. 46-57.

5. Boponaй B.A. Аналіз методичних підходів оцінки стану і рівня забезпечення системи економічної безпеки підприємства / B.A. Воропай // Культура народов Причерноморья. - 2013. - № 257. - С. 190-195.

6. Денисенко М.П. Пріоритетні напрями посилення економічної безпеки / М.П. Денисенко, П.Т. Колісніченко // Економіка та держава. - 2017. - № 3. - С. 31-35. 
7. Сумець О.М. Оцінка стану економічної безпеки підприємств різної галузевої приналежності / O.M. Сумець, A.B. Kopon // Вчені записки Університету «КРОК». - 2017. - Вип. 48. - С. 122-128.

8. Якименко Ю.М. Вибір підходу до оцінки економічної безпеки бізнесу в організації / Ю.М. Якименко // Економіка. Менеджмент. Бізнес. - 2015. - № 3 (13). - С. 133-142.

9. Бутник Д.В. Критерии и показатели экономической безопасности / Д.В. Бутник // Управління фінансовоекономічною безпекою: інформаційно-аналітичне забезпечення та конкурентна розвідка : матеріали конференції / Харківський національний університет міського господарства імені О.M. Бекетова. - 2013 [Електронний ресурс]. - Режим доступу : https://eprints.kname.edu.ua/38580/1/36-38.pdf

10. Козлобаева E.A. Комплексная оценка экономической безопасности сельскохозяйственной организации / E.A. Козлобаева, С.И. Яблоновская // Вестник Воронежского государственного аграрного университета. - 2018. № 3 (58). - С. 175-182.

11. Приходько В.П. Методологічні підходи до оцінки економічної безпеки підприємств / В.П. Приходько // Агросвіт. - 2013. - № 13. - С. 33-36.

12. Довбня С.Б. Діагностика економічної безпеки підприємства як інструмент визначення напрямків його інноваційного розвитку / С.Б. Довбня, Н.Ю. Гічова // Економічний вісник НГУ. - 2008. - № 3. - С. 36-42.

13. Артамонова Н.С. Визначення рівня економічної безпеки підприємства задля забезпечення ефективного адміністрування / Н.С. Артамонова, А.В. Атрашкова // Економіка: реалії часу : наук. журнал. - 2012. № 1 (2). - С. 19-23.

14. Нусінов В.Я. Методологічні засади оцінки багаторівневих показників (на прикладі економічної безпеки підприємства) / В.Я. Нусінов, С.В. Мішук // Вісник Житомирського державного технологічного університету. Серія : Економіка, управління та адміністрування. - 2019. - № 2 (88). - С. 36-45.

15. Нусінов В.Я. Совершенствование корпоративного управления компаниями, находящимися в финансовоэкономическом кризисе / В.Я. Нусінов // Вісник університету банківської справи. - 2018. - № 1 (31). C. $114-121$.

\section{References:}

1. Kozachenko, G.V. and Pogorelov, Ju.S. (2015), Ocinjuvannja ekonomichnoi' bezpeky pidpryjemstva: analiz osnovnyh pidhodiv. Menedzhment bezpeky derzhavy, regionu, pidpryjemstva: problemy i vyklyky s'ogodennja, kol. Monografija, in Zhyvko, Z.B. and Babec', I.G. (ed.), Liga-Pres, L'viv, pp. 238-251.

2. Chernjak, G.M. (2015), «Ocinjuvannja rivnja ekonomichnoi' bezpeky energetychnyh pidpryjemstv v umovah jevrointegracii'», Ekonomichnyj visnyk Nacional'nogo tehnichnogo universytetu Ukrai'ny "Kyi'vs'kyj politehnichnyj instytut», No. 12, pp. 159-166.

3. Kovalenko, D.I. and Nehoroshyh, V.O. (2017), «Ocinjuvannja rivnja finansovo-ekonomichnoi' bezpeky pidpryjemstva v umovah nestabil'nosti: teoretyko-metodychnyj aspekt», Internauka, mizhnarodnyj naukovyj zhurnal, Serija Ekonomichni nauky, No. 6 (6), pp. 33-38.

4. Gnylyc'ka, L.V. (2011), «Analiz metodologichnyh pidhodiv do ocinky stanu ta rivnja ekonomichnoi' bezpeky sub'jektiv gospodarjuvannja», Naukovyj visnyk L'vivs'kogo derzhavnogo universytetu vnutrishnih sprav, Serija Ekonomichni nauky, No. 2, pp. 46-57.

5. Voropaj, V.A. (2013), «Analiz metodychnyh pidhodiv ocinky stanu i rivnja zabezpechennja systemy ekonomichnoi' bezpeky pidpryjemstva», Kul'tura narodov Prychernomor'ja, No. 257, pp. 190-195.

6. Denysenko, M.P. and Kolisnichenko, P.T. (2017), «Priorytetni naprjamy posylennja ekonomichnoi' bezpeky», Ekonomika ta derzhava, No. 3, pp. 31-35.

7. Sumec', O.M. and Korop, A.V. (2017), «Ocinka stanu ekonomichnoi' bezpeky pidpryjemstv riznoi' galuzevoi' prynalezhnosti», Vcheni zapysky Universytetu «KROK», Vol. 48, pp. 122-128.

8. Jakymenko, Ju.M. (2015), «Vybir pidhodu do ocinky ekonomichnoi' bezpeky biznesu v organizacii'», Ekonomika. Menedzhment. Biznes, No. 3 (13), pp. 133-142.

9. Butnik, D.V. (2013), «Kriterii i pokazateli jekonomicheskoj bezopasnosti», Upravlinnja finansovo-ekonomichnoju bezpekoju: informacijno-analitichne zabezpechennja ta konkurentna rozvidka, Materiali konferenciï, Harkivs'kij nacional'nij universitet mis'kogo gospodarstva imeni O.M. Beketova, [Online], available at: https://eprints.kname.edu.ua/38580/1/36-38.pdf

10. Kozlobaeva, E.A. and Jablonovskaja, S.I. (2018), «Kompleksnaja ocenka jekonomicheskoj bezopasnosti sel'skohozjajstvennoj organizacii», Vestnik Voronezhskogo gosudarstvennogo agrarnogo universiteta, №. 3 (58), pp. 175-182.

11. Pryhod'ko, V.P. (2013), «Metodologichni pidhody do ocinky ekonomichnoi' bezpeky pidpryjemstv», Agrosvit, No. 13 , pp. 33-36.

12. Dovbnja, S.B. and Gichova, N.Ju. (2008), «Diagnostyka ekonomichnoi' bezpeky pidpryjemstva jak instrument vyznachennja naprjamkiv jogo innovacijnogo rozvytku», Ekonomichnyj visnyk NGU, No. 3, pp. 36-42.

13. Artamonova, N.S. and Atrashkova, A.V. (2012), «Vyznachennja rivnja ekonomichnoi' bezpeky pidpryjemstva zadlja zabezpechennja efektyvnogo administruvannja», Ekonomika: realii' chasu, nauk. zhurnal, No. 1 (2), pp. 19-23.

14. Nusinov, V.Ja. and Mishhuk, Je.V. (2019), «Metodologichni zasady ocinky bagatorivnevyh pokaznykiv (na prykladi ekonomichnoi' bezpeky pidpryjemstva)», Visnyk Zhytomyrs'kogo derzhavnogo tehnologichnogo universytetu, Serija Ekonomika, upravlinnja ta administruvannja, No. 2 (88), pp. 36-45.

15. Nusinov, V.Ja. (2018), «Sovershenstvovanie korporativnogo upravlenija kompanijami, nahodjashhimisja v finansovo-jekonomicheskom krizise», Visnik universitetu bankivs'koï spravi, No. 1 (31), pp. 114-121.

Міщук Євгенія Володимирівна - кандидат економічних наук, доцент, доцент кафедри обліку, оподаткування, публічного управління та адміністрування Криворізького національного університету

Наукові інтереси:

- економіка підприємств; економічна безпека; економічний аналіз; публічне управління.

E-mail: tdutybz.077@gmail.com. 